*УДК 336.22

Гаврилюк О.О., к.е.н., доцент

Костюкевич В.В.

Луцький національний технічний університет

\title{
ЗАРУБІЖНИЙ ДОСВІД ОПОДАТКУВАННЯ ПІДПРИЕМСТВ ЛІСОВОГО ГОСПОДАРСТВА
}

У статті досліджено особливості оподаткування лісового господарства в Сполучених Штатах Америки, Франції та Ірландії. Визначено основні напрями реформування податкової системи України в сфері лісокористування.

Ключові слова: лісове господарство, оподаткування, зарубіжний досвід, лісове законодавство.

\section{Havryliuk O., Kostiukevych V. FOREIGN EXPERIENCE OF FORESTRY TAXATION}

The article investigated the features of forestry taxation in the United States of America, France, and Iceland. The main directions of reforming the tax system of Ukraine in the field of forest management are defined. The purpose of the study is to analyze the experience of foreign countries on forestry taxation and the effective use of forestry potential of countries with the prospect of introducing effective practices into the system of taxation of domestic economic entities.

Research on scientific articles on forestry taxation has shown that many traditions in environmental management are remnants of previous systems of management, and therefore far behind Western practice. However, Ukraine's orientation to the European Union requires that Ukrainian legislation in the field is consistent with EU forest management conditions.

Despite the considerable attention of scientists on the issues of improving and reforming the existing system of taxation of forestry enterprises, many problems remain regarding the administration of resource payments and the application of their mechanisms in forestry.

It is determined that the most optimal for Ukraine is the American tax system. Rates and methods of taxation differ significantly for different types of ownership of forest land. Wood is classified into three types:

- personal use (mainly for personal use, without profit);

- investment real estate (mainly to profit from rising timber or asset prices);

\footnotetext{
* Гаврилюк О.О., Костюкевич В.В.
} 
- business property (with regular, active and permanent profit from logging activities).

American incentive and subsidy methods are implemented in the form of federal and state income tax benefits; favorable management of the environment of wood and wildlife in state and local property taxes; deductions for the donation of land or the right to build it in conditions of permanent conservation of easements; direct incentive savings through special bills and other federal, state, and private programs.

Federal tax policy reforms have increased the income tax for high-income businesses and changed the real estate tax by touching some forest owners and producers. However, despite flexible tax policies, forest land taxes and forest fund use continue to fund state and local budgets. That is why it is possible to implement such system in the economy of Ukraine.

Overseas taxation is more loyal to businesses that focus not on profit, but for those whose forest is primarily a source of income, there is a progressive rate of interest on income tax. The fact that Ukraine's European integration requires reforming the economy and forestry, including the tax system will gradually move closer to the European one.

Key words: forestry, taxation, foreign experience, forestry legislation.

\section{Гаврилюк О.А., Костюкевич В.В. ЗАРУБЕЖНЫЙ ОПЫТ НАЛОГООБЛОЖЕНИЯ
ПРЕДПРИЯТИЙ ЛЕСНОГО ХОЗЯЙСТВА}

В статье исследованы особенности налогообложения лесного хозяйства в США, Франции и Ирландии. Определены основные направления реформирования налоговой системы Украины в сфере лесопользования.

Ключевые слова: лесное хозяйство, налогообложения, зарубежный опыт, лесное законодательство.

Постановка проблеми у загальному вигляді та її зв'язок 3 важливими науковими і практичними завданнями. Дослідження наукових статей, щодо оподаткування в лісовому господарстві показало, що багато традицій в природокористуванні є пережитками попередніх систем господарювання, а отже значно відстають від західної практики. Проте, спрямованість України до Європейського Союзу вимагає відповідності екраїнського законодавства галузі умовам лісокористування в Свропейському Союзі.

Не зважаючи на значну увагу науковців щодо питань удосконалення та реформування існуючої системи оподаткування підприємств лісової галузі, невирішеними залишаються багато проблем адміністрування ресурсних платежів та застосування їх механізмів 
"Економічні науки". - Серія "Облік і фінанси". - Випуск 16 (61). - 2019.

в лісовому господарстві.

Аналіз основних досліджень, у яких започатковано вирішення проблеми. Над питанням вирішення зазначених проблем задумувалися багато науковців, серед яких В.А. Голян, Р.В. Леньо [7], С.О. Сучек [6], Т.П. Сгорова [5], В.П. Морозов [4], а також багато інших практиків та теоретиків. Проте, дослідження їх наукових робіт показало, що вивчення питання оподаткування лісового господарства є все ще актуальним, оскільки євроінтеграція України вимагає адаптації вітчизняного законодавства сучасним реаліям господарювання.

Цілі статті. Метою дослідження є аналіз досвіду зарубіжних країн, щодо оподаткування лісового господарства та ефективного використання лісового потенціалу країн 3 перспективою впровадження ефективних практик у систему оподаткування вітчизняних господарюючих суб'єктів.

Виклад основного матеріалу дослідження з повним обгрунтуванням отриманих наукових результатів.

Сполучені Штати мають широкий спектр інвестиційної та податкової політики, яка сприяє довгостроковому використанню лісових ресурсів, надає послідовні ринкові стимули для ведення лісогосподарської діяльності, а також передбачає стимулювання при використанні лісу з дотриманням екологічних та неринкових цінностей. Податки та заохочення суттєво впливають на стійке управління процесом використання лісових земель, зокрема, витрати на ведення лісового господарства, заохочуючи виробництво та збереження лісів або надаючи перевагу певним секторам та заходам.

Американські методи надання стимулів та субсидій реалізуються у вигляді федеральних та державних пільг 3 податку на прибуток; сприятливого поводження з середовищем існування деревини та дикої природи в державних та місцевих податках на майно; відрахувань на дарування земельної ділянки або права на їі забудову в умовах постійного збереження сервітутів; прямі заохочувальні заощадження за рахунок спеціальних законопроектів та інших федеральних, державних та приватних програм.

Федеральна політика 3 податку на прибуток значно заохочує вирощування деревини та включає: трактування доходів 3 дереви- 
ни, як довгострокового приросту капіталу для всіх власників; відрахування та прискорену амортизацію витрат на лісовідновлення для власників сімейних лісів; врахування витрат на управління та витрати для активних власників лісів; зниження ставок податку (порівняно 3 корпораціями) для організацій з управління інвестиціями в землю лісогосподарського призначення та різноманітні інвестиційні фонди.

Власники лісових земель у США також можуть розраховувати на пільги 3 оподаткування деревини, щоб компенсувати тривалий цикл вирощування дерев та значні попередні витрати на посадку дерев та управління лісом, включаючи охорону здоров'я лісу та сплату податку на майно, відсотки за користування кредитами.

Важливо також знати, що американський податковий режим суттєво відрізняється для різних типів власності на лісові землі. Деревина класифікується на три типи:

- особистого користування (головним чином для особистого використання, без отримання прибутку);

- інвестиційна нерухомість (головним чином для отримання прибутку від зростання цін деревини або активів);

- бізнес-майно (з регулярним, активним та постійним прибутком від лісозаготівельної діяльності).

Реформи федеральної податкової політики збільшили податок на прибуток для підприємств із високим рівнем доходу та внесли зміни до податку на нерухомість, торкнувшись деяких власників лісових земель та виробників. Однак, не зважаючи на гнучку податкову політику, податки на землі лісогосподарського призначення i використання лісового фонду продовжують фінансувати державні та місцеві бюджети [1].

У Франції лісове господарство охоплює низку видів діяльності від лісництва та лісозаготівель, і від первинної, механічної обробки деревини до виготовлення основних деревних виробів. Це створює приблизно 425000 прямих чи непрямих робочих місць, що $\epsilon$ значною часткою французької економіки, хоча ліс досі вважається «недостатньо експлуатованим» [2].

Ліси Франції поділяють на дві категорії:

- ліси, які використовуються для виробництва деревини, тобто ліси, де немає законних, економічних або технічних обмежень 
на вирубку; вони складають майже 91\% французьких лісів загалом. У цій категорії розрізняють культивовані та необроблювані ліси. Приріст оброблюваних лісів становить основу виробництва в системі лісового господарства. Природний приріст необроблених лісів відображається у звітності французьких підприємств у розділі «інші зміни активів»;

- ліси, які не використовуються для виробництва деревини, тобто ліси, де $\epsilon$ законні, економічні або технічні обмеження на вирубку; вони становлять майже 9\% усіх лісів. У межах цієї категорії розрізняють захищені ліси, розташовані переважно у національних парках та природних заповідниках та лісах, які конкретно не $\epsilon$ захищені, але розташовані у віддалених районах, де витрати на вирощування, технічне обслуговування, збереження, вирубку та транспортування були б зависокими.

Що стосується оподаткування, у Франції ставка податку на прибуток складає 28\%, якщо дохід не перевищує 500 тис. євро та $33 \%$, якщо дохід вище цієї суми [2].

Проте, у Франції існує також таке поняття, як «лісогосподарська група», яка передбачає цивільне партнерство для заохочення лісовідновлення, покращення та збереження лісових масивів, а також для розвитку здорового лісового господарства.

Для учасників лісогосподарських груп діють наступні пільги:

- знижка на податок на багатство. Власники акцій у лісових групах можуть скористатись зниженням податку на багатство на 50\%, до максимальної суми в розмірі 90000 євро;

- знижка 3 податку на прибуток. Зниження податку на прибуток на $18 \%$ від прибутку або придбання акцій у лісовій групі, до обмеження в 5700 євро для однієї особи та 11400 євро для сімейного господарства, можливе, якщо суб'єкти оподаткування зберігають у власності землі лісогосподарського призначення протягом восьми років [1].

Умовами користування даної групи є повністю громадське призначення (розвиток, вдосконалення, обладнання, збереження або управління лісовим масивом; придбання лісів або земель для лісонасадження), виключаючи всі інші операції, такі як обробка продуктів лісового господарства.

Ірландська лісова та лісообробна галузь, що включає вирощування, заготівлю та переробку лісової продукції, формує знач- 
ний і зростаючий внесок у економіку Ірландії.

У порівнянні з рештою Європи Ірландія має низький рівень лісового покриву. Трохи більше $40 \%$ земель у межах Європейського Союзу (СС) віднесено до лісових земель.

Ірландія має дуже сприятливий податковий режим для отримання прибутку, пов’язаного 3 лісовим господарством, для багатьох платників податків [3].

Найвідоміша податкова пільга застосовується для податкових надходжень грантів та премій. У так званих Податкових актах зазначено, що прибутки отримані від освоєння лісових масивів в Iрландії, що управляються на комерційній основі та 3 метою реалізації прибутку звільняються від податку на прибуток та податку на прибуток підприємств. Фактично це означає, що існують лісові субсидії, а продаж лісу і вирубка практично звільнені від податку на прибуток. Такі преференції поширюється і на дивіденди, виплачені компаніями з прибутку стосовно доходів лісових масивів.

Для того, щоб застосовувати податкові пільги, землі повинні управляти на комерційних засадах 3 метою одержання прибутку. Фізична особа, яка отримує дохід, повинна включати інформацію про результати лісокористування у свою річну декларацію 3 податку на прибуток. Однак, звільнення не поширюється на платежі 3 соціального страхування, які залежать від доходу. Гранти та субсидіï, отримані компанією, яка володіє і використовує лісові землі Ірландії, не оподатковуються корпоративним податком [3].

Вирубка лісових масивів - це також частина об'єктів оподаткування діяльності лісогосподарських підприємств, що безпосередньо обчислюється, виходячи із вартості дерев. Однак, такий вид діяльності виключається з обчислення податку на приріст капіталу. Це правило поширюється також на суми капіталу, отримані за страховим полісом щодо знищення: шкоди; травмування дерев вогнем або інші небезпеки.

Ще однією складовою європейської системи оподаткування є екологічний податок. Це податок, податковою базою якого є фізична одиниця того, що має доведений, специфічний негативний вплив на навколишнє середовище і визначений в європейській системі рахунків.

Європейська статистика виділяє чотири різні категорії еколо- 
гічних податків, що стосуються: енергетики, транспорту, забруднення та використання ресурсів.

Екологічні податки все частіше використовуються для впливу на поведінку суб'єктів господарювання європейських країн, чи то виробники чи споживачі. Ці податки також приносять дохід, який потенційно може використовуватися урядом для збільшення витрат на охорону навколишнього природного середовища або ефективне управління природними ресурсами.

Висновки. Таким чином, проаналізувавши зарубіжну практику, можна зробити висновок, що оподаткування за кордоном $\epsilon$ лояльнішим до підприємств, які орієнтуються не на одержання прибутку, а для тих, кому ліс є це перш за все джерелом доходу. Існує прогресивна ставка відсотка податку на прибуток. Проте, євроінтеграція України вимагає реформування економіки і лісової галузі в тому числі, а отже податкова система буде поступово наближатися до європейської.

1. Gubbage F.W., McGinley K., Arbogast T. Taxation and other economic strategies that affect the sustainable management of forests. US Forest Sustainable indicator, 2018. P. 1-3.

2. Ryan M., Donoghue C., Kinsella A. The potential impact of differential taxation and social protection measures on farm afforestation decisions. Irish Forestry, 2017.

3. Лісове господарство Франції. URL: https://www.the-forest-time.com/en/theforest-economy-in-france (дата звернення: 25.11.2019).

4. Мороз В.П. Досвід зарубіжних країн щодо оподаткування лісового господарства: еколого-економічні аспекти. Науковий вісник НЛTУ України, 2010. URL: http://ndi-fp.nusta.com.ua/files/doc/publications/NDI_Ekologichne_ opodatkuvannya_030214_out.pdf (дата звернення: 25.11.2019).

5. Єгорова Т.П. Європейське лісове законодавство як інноваційний елемент удосконалення національної лісової політики. Адаптація до права ЄС регулювання економіки України в сучасних умовах, 2015. С. 86.

6. Сучек С. Екологічна підтримка: європейський досвід та перспективи його використання в українських реаліях. Економічний журнал Східноєвропейського національного університету імені Лесі Українки, 2018. С. 85-93.

7. Леньо Р.В. Перспективні напрями впровадження зарубіжного досвіду в систему управління лісовим господарством України. Державне управління: теорія та практика, 2012. С. 23-29. 